\section{Pengaruh Pemberian Tepung Tempe terhadap Kadar Kolesterol Total Darah Mencit (Mus musculus) Hiperkolesterol}

\author{
Heryl Rumtal \\ Rosdiana Ngitung
}

\section{A. Mu'nisa}

\begin{abstract}
Abstrak. Penelitian ini adalah penelitian eksperimen yang bertujuan untuk mengetahui pengaruh pemberian tepung tempe terhadap kadar kolesterol total darah mencit (Mus musculus) hiperkolesterol. Variabel bebas dalam penelitian ini adalah tepung tempe sedangkan variabel terikatnya adalah kadar kolesterol total darah mencit (Mus musculus). Subjek penelitian ini adalah mencit jantan Strain ICR (Imprinting Control Region) sebanyak 25 ekor dengan umur 3 bulan yang dibagi menjadi 5 kelompok perlakuan yaitu kelompok normal, kelompok hiperkolesterol, pemberian tepung tempe dosis $10 \mathrm{~g} / \mathrm{hari} / \mathrm{BB}$ (P1), $20 \mathrm{~g} / \mathrm{hari} / \mathrm{BB}$ (P2) dan $25 \mathrm{~g} / \mathrm{hari} / \mathrm{BB}$ (P3). Tepung tempediberikan setelah pemberian pakan kolesterol. Semua mencit diperiksa kadar kolesterol darahnya setelah masa perlakuan kemudian hasilnya dianalisa menggunakan uji ANOVA dan dilanjutkan dengan uji Ducan. Hasil penelitian menunjukkan bahwa pemberian tepung tempe berpengaruh terhadap penurunan kadar kolesterol darah mencit (Mus musculus) pada dosis $10 \mathrm{~g} /$ hari/BB, $20 \mathrm{~g} /$ hari/BB dan $25 \mathrm{~g} /$ hari/BB. Pemberian dosis 25 $\mathrm{g} /$ hari/BB menunjukkan dosis terbaik menurunkan kadar kolesterol dalam penelitian ini

Kata Kunci: tepung tempe, kolesterol, hiperkolesterol, mencit (Mus musculus).
\end{abstract}

\section{Pendahuluan}

Indonesia merupakan negara berkembang, hal ini menyebabkan terjadinya perubahan gaya hidup di dalam masyarakatnya termasuk dalam perubahan perilaku konsumsi makanan. Perilaku konsumsi makanan yang beresiko menyebabkan penyakit degeneratif seperti PJK yang digemari oleh masyarakat antara lain kebiasaan mengonsumsi makanan atau minuman manis, asin, berlemak tinggi atau makanan yang dibakar atau dipanggang, diawetkan, berkafein dan berpenyedap rasa (Riskesdas, 2013).

Kolesterol merupakan salah satu jenis lipid utama yang terdapat di dalam plasma dan memegang peranan penting dalam sintesis membran sel, hormon steroid, dan asam empedu. Secara alami, tubuh manusia memerlukan kolesterol. Kolesterol merupakan komponen esensial membran sel, komponen utama sel otak, dan jaringan saraf dan bahan baku untuk pembentukan hormon steroid yang dihasilkan oleh korteks adrenal, testis, dan ovarium, serta dibutuhkan untuk sintesis asam/garam empedu dan sintesis vitamin D (Achmad, 2001 dalam Erni et al., 2014). Kolesterol tidak sepenuhnya merupakan racun dalam tubuh, karena kolesterol merupakan unsur penting dalam tubuh yang diperlukan untuk mengatur proses kimiawi di

\section{BIONATURE}

p-ISSN 1411 - 4720

e-ISSN 2654 - 5160

Abstract. This research is experimental which aims to determine the effect of giving Tempe Flour to total blood cholesterol concentration of hypercholesterol mice (Mus musculus). The independent variable of this research Tempe Flour while the dependent variable is the total blood cholesterol concentration of mice (Mus musculus). The subject of this research is 25 male ICR strain (Imprinting Control Region) mice with 3 months age divided 5 treatment groups which are normal group, hypercholesterol group, giving of tempe flour at dose of $10 \mathrm{~g} /$ day / $B B(P 1), 20 \mathrm{~g} /$ days / BB (P2) and $25 \mathrm{~g} /$ day / BB (P3). Tempe flour is given after the giving of cholesterol feed. All mices

blood cholesterol concentration were check after the time of treatment. The result is analyz by using ANOVA with Ducan test. The result of this research show that the giving of Tempe Flour affected the decrease of blood cholesterol concentration of mice (Mus musculus) in dose of $10 \mathrm{~g} /$ day $/ B B, 20$ $\mathrm{g} /$ day/BB and $25 \mathrm{~g} /$ day $/ \mathrm{BB}$. Dose of 25 $g /$ day/BB showed an effective dose for lowering cholesterol in the research. Keywords: tempe flour, cholesterol, hypercholesterol, mencit (Mus musculus)

Heryl Rumtal Universitas Negeri Makassar Indonesia

Rosdiana Ngitung Universitas Negeri Makassar Indonesia

A. Mu'nisa Universitas Negeri Makassar Indonesia 
dalam tubuh, tetapi kolesterol dalam jumlah tinggi bisa menyebabkan terjadinya aterosklerosis yang akhirnya akan berdampak pada penyakit jantung koroner (Rahayu, 2005).

Hiperkolesterolemia merupakan suatu kondisi yang ditandai dengan kadar kolesterol total dalam darah melebihi normal yaitu $\geq 200 \mathrm{mg} / \mathrm{dL}$, orang yang memiliki kadar kolesterol total $\geq 200 \mathrm{mg} / \mathrm{dL}$ terbukti dua kali lebih besar terancam panyakit jantung koroner, kemudian meningkat menjadi empat kali lebih besar jika kadar kolesterolnya mencapai $300 \mathrm{mg} / \mathrm{dL}$ (Astawan et al., 2017).

Tempe dibuat dari kedelai melalui proses fermentasi menggunakan kapang Rhizopus sp. Dibandingkan kedelai utuh, tempe memiliki beberapa keunggulan, diantaranya daya cerna protein, karbohidrat dan lemaknya lebih baik, kandungan beberapa vitamin lebih tinggi, ketersediaan (bioavalabilitas) mineral menjadi lebih baik karena hilangnya faktor antigizi, serta ditemukannya berbagai komponen bioaktif yang sebelumnya tidak ada pada kedelai. Beberapa komponen bioaktif ini memiliki aktivitas antioksidan, antidiare serta mencegah penyakit degeneratif (Astuti et al., 2000; Nout dan Kiers, 2005 dalam Suwarno et al., 2014). Selain kualitas gizinya lebih baik dari kedelai utuhnya, tempe diketahui berpotensi sebagai pangan hipoalergenik, karena proses fermentasi dapat mengurangi sifat alergenisitas protein kedelai (Wilson et al., 2005; Song et al., 2008 dalam Suwarno et al., 2014).

Senyawa pada tempe yang berpengaruh terhadap penurunan kolesterol antara lain protein, asam lemak tidak jenuh tungal dan majemuk, isoflavon dan anthosianin. Penelitian efek hipokolesterolemik tempe kedelai pada hewan coba dan manusia telah dilakukan oleh beberapa peneliti. Salah satunya tentang efek pemberian berbagai ekstrak kedelai terhadap kadar total kolesterol pada mencit galur Balb- $C$ jantan yang diinduksi pakan tinggi lemak. Ekstrak yang digunakan terdiri dari ekstrak etanol biji kedelai, fraksi etil asetat tempe, dan ekstrak protein kedelai, setelah 14 hari perlakuan, semua jenis ekstrak yang digunakan menunjukkan terjadinya penurunan kadar total serum kolesterol (Astawanet al., 2017) dan juga salah satunya penelitian pemberian tempe kedelai kuning sebanyak 160 gram setiap hari selama 4 minggu dapat memperbaiki profil lipid yaitu menurunkan kadar kolesterol total sebesar 6\%, kolesterol LDL sebesar 5.8\% dan TGA sebesar 11.7\%, namun tidak dapat meningkatkan kadar kolesterol HDL (Diah, 2011 dalam Priastiti, 2013).

Berdasarkan uraian di atas, maka perlu dilakukan uji pengaruh pemberian tepung tempe terhadap kadar kolesterol darah mencit (Mus musculus) yang mengalami hiperkolesterol.

\section{Metode Penelitian}

\section{Alat}

Alat-alat yang digunakan pada penelitian ini adalah oven, pengukur kolesterol Nesco multicheck, gelas kimia (Pyrex) $500 \mathrm{~mL}$, timbangan analitik, batang pengaduk, sprayer, kompor, blender, gunting, rang kawat, kandang mencit, perlengkapan makan dan minum hewan uji, saringan, panci, toples kaca dan baskom.

\section{Bahan}

Tempe, mencit (Mus musculus), strip kolesterol Nesco multicheck, kuning telur ayam ras, spoit $1 \mathrm{ml}$, alkohol 70\%, SENSI gloves, kertas saring, kapas, tissue, pakan mencit AD II dan aluminium foil. 


\section{Prosedur Kerja}

Meliputi pengkajian literature, pengambilan sampel, pembuatan tepung tempe, pembuatan pakan kolesterol, pemeliharaan hewan uji dan Desain penelitian

\section{Desain penelitian}

Sebanyak 25 ekor mencit Strain ICR (Imprinting Control Region) umur 3 bulan dengan berat badan 18-30 g, dibagi menjadi 5 kelompok perlakuan. Sebelum perlakuan, mencit diaklimatisasi selama 2 minggu dengan pemberian pakan AD II dan air minum secara ad libitum. Selain itu, mencit dibuat hiperkolesterolemia dengan pemberian pakan kuning telur yang diberikan setiap hari selama 14 hari sampai diyakini terjadi peningkatan kadar kolesterol (hiperkolesterolemia). Perlakuannya adalah sebagai berikut:

1) Kelompok I (Normal), yaitu mencit hanya diberikan pakan standar AD II selama masa percobaan.

2) Kelompok II (Hiperkolesterol), yaitu mencit diberikan pakan standar AD II selama masa percobaan dan diberikan pakan kuning telur selama 14 hari.

3) Kelompok Perlakuan I, yaitu mencit diberikan pakan standar AD II dan diberikan pakan kuning telur selama 14 hari, setelah itu diberikan tepung tempe $10 \mathrm{~g} / \mathrm{hari} / \mathrm{BB}$ selama masa 14 hari.

4) Kelompok Perlakuan II, yaitu mencit diberi pakan standar AD II dan diberikan pakan kuning telur selama 14 hari, setelah itu diberikan tepung tempe $20 \mathrm{~g} / \mathrm{hari} / \mathrm{BB}$ selama 14 hari.

5) Kelompok Perlakuan III, yaitu mencit diberi pakan standar AD II dan diberikan pakan kuning telur selama 14 hari, setelah itu diberikan tepung tempe $25 \mathrm{~g} / \mathrm{hari} / \mathrm{BB}$ selama 14 hari.

Pengukuran dilakukan dengan mengambil sampel darah mencit melalu vena pada ekornya dengan cara ekor mencit jantan diusapkan alkohol 70\% dengan menggunakan kapas. Ekor mencit jantan dijulurkan dan dipotong sekitar $1 \mathrm{~mm}$ dari ujung ekor dengan silet atau gunting yang steril. Darah ditampung dalam strip kolesterol sebanyak $15 \mu \mathrm{L}$. Kadar kolesterol diuji dengan menggunakan alat pengukur kolesterol multicheck. Ekor mencit jantan diusapkan alkohol agar darah tidak mengalir secara terus-menerus dan diberi antibiotik (Mu'nisa, 2008).

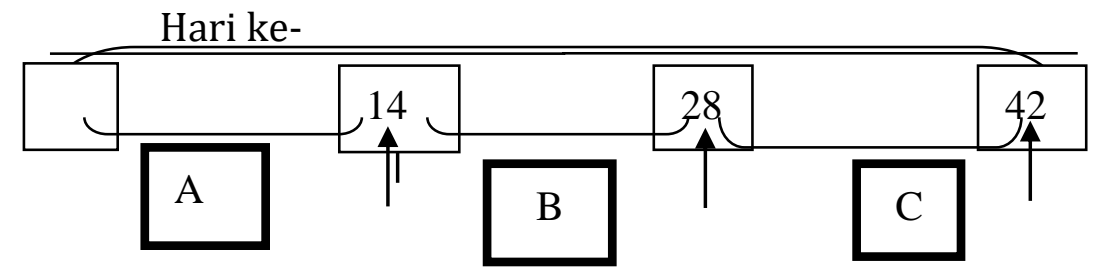

Gambar 1. Diagram Alur Perlakuan dan Pengambilan Data pada Hewan Uji

Keterangan

A. Masa adaptasi

B. Masa pemberian pakan kuning telur

C. Masa pemberian tepung tempe

Pengukuran kadar kolesterol total darah mencit 


\section{Hasil Penelitian}

Berdasarkan penelitian yang telah dilakukan, terdapat lima kelompok perlakuan yaitu kelompok I (normal) mencit yang hanya diberikan pakan standar. Kelompok II (hiperkolesterol) mencit yang diberikan pakan standar dan pakan kolesterol. Kelompok III (perlakuan 1) mencit yang diberikan pakan standar dan pakan kuning telur, kemudian pemberian sampel tepung tempe sebanyak $10 \mathrm{~g} /$ hari/BB selama 14 hari. Kelompok IV (perlakuan 2) mencit yang diberikan pakan standar dan pakan kuning telur, kemudian diberikan sampel tepung tempe sebanyak $20 \mathrm{~g} /$ hari/BB selama 14 hari. Kelompok V (perlakuan 3) mencit yang diberikan pakan standar dan pakan kuning telur, kemudian diberikan sampel tepung tempe sebanyak 25 g/hari/BB selama 14 hari.

\section{Tabel 1. Nilai Rata-Rata Kadar Kolesterol (mg/dL) Mencit (Mus musculus) Sebelum dan Setelah Pemberian Tepung Tempe.}

\begin{tabular}{|c|l|c|c|c|}
\hline \multirow{2}{*}{ No. } & \multirow{2}{*}{ Perlakuan } & \multicolumn{3}{|c|}{ Rata-rata kadar kolesterol total (mg/dL) mencit (Mus } \\
& & Tasculus) & \multicolumn{3}{|c|}{ Tahap I } & Tahap II & Tahap II \\
\cline { 3 - 5 } & & $88,40^{\mathbf{a}}$ & $89,00^{\mathbf{a}}$ & $90,80^{\mathbf{a}}$ \\
\hline 1. & Kelompok Normal & $88,00^{\mathbf{a}}$ & $163,00^{\mathbf{b}}$ & $212,00^{\mathbf{c}}$ \\
\hline 2. & Hiperkolesterol & $89,00^{\mathbf{a}}$ & $164,00^{\mathbf{b}}$ & $142,50^{\mathbf{b}}$ \\
\hline 3. & $10 \mathrm{~g} /$ hari/BB & $86,20^{\mathbf{a}}$ & $183,00^{\mathbf{c}}$ & $149,75^{\mathbf{b}}$ \\
\hline 4. & $20 \mathrm{~g} / \mathrm{hari} / \mathrm{BB}$ & $86,60^{\mathbf{a}}$ & $179,60^{\mathbf{b c}}$ & $107,00^{\mathbf{b}}$ \\
\hline 5. & $25 \mathrm{~g} /$ hari/BB &
\end{tabular}

Keterangan: - Hurufyang sama dalam satu kolom menunjukkan "berbeda tidak nyata".

- Hurufyang berbeda menunjukkan "berbeda nyata".

- Huruf yang berbeda antara baris dalam satu kolom menunjukkan "sangat berbeda nyata".

\section{Pembahasan}

Hasil uji statistik menggunakan ANOVA (Analysis of Variance) yang dilanjutkan dengan uji Ducan. Nilai rata-rata kadar kolesterol pada tahap pertama, sebelum pemberian pakan kuning telur, menunjukkan bahwa kelompok normal $(88,40 \mathrm{mg} / \mathrm{dL})$ berbeda tidak nyata terhadap semua kelompok perlakuan. Kelompok hiperkolesterol $(88,40 \mathrm{mg} / \mathrm{dL})$ juga berbeda tidak nyata terhadap kelompok dosis $10 \mathrm{~g} / \mathrm{hari} / \mathrm{BB}(89,00 \mathrm{mg} / \mathrm{dL})$, kelompok dosis 20 $\mathrm{g} / \mathrm{hari} / \mathrm{BB}(86,20 \mathrm{mg} / \mathrm{dL})$ dan kelompok dosis $25 \mathrm{~g} / \mathrm{hari} / \mathrm{BB}(86,60 \mathrm{mg} / \mathrm{dL})$. Pada tabel terlihat nilai rata-rata kadar kolesterol terendah adalah pada kelompokdosis $20 \mathrm{~g} / \mathrm{hari} / \mathrm{BB}$ yaitu 86,20 $\mathrm{mg} /$ dLdan nilai rata-rata kadar kolesterol tertinggi yaitu $89,00 \mathrm{mg} / \mathrm{dL}$ pada kelompok dosis 10 g/hari/BB (Tabel 1.).

Rata-rata kadar kolesterol tahap kedua setelah pemberian pakan kuning telur menunjukkan kelompok normal $(89,00 \mathrm{mg} / \mathrm{dL})$ sangat berbeda nyata terhadap semua kelompok perlakuan. Pada kelompok hiperkolesterol $(163,00 \mathrm{mg} / \mathrm{dL})$ memberi pengaruh berbeda nyata terhadap kelompok dosis $25 \mathrm{~g} / \mathrm{hari} / \mathrm{BB}(179,60 \mathrm{mg} / \mathrm{dL})$, namun sangat berbeda nyata terhadap kelompok dosis $20 \mathrm{~g} / \mathrm{hari} / \mathrm{BB}(183,00 \mathrm{mg} / \mathrm{dL})$. Pada kelompok dosis 10 $\mathrm{g} /$ hari/BB $(164,00 \mathrm{mg} / \mathrm{dL})$ memberi pengaruh berbeda tidak nyata terhadap kelompok hiperkolesterol $(163,00 \mathrm{mg} / \mathrm{dL})$, namun sangat berbeda nyata dengan kelompok normal $(89,00 \mathrm{mg} / \mathrm{dL})$. Pada kelompok dosis $25 \mathrm{~g} / \mathrm{hari} / \mathrm{BB}(179,60 \mathrm{mg} / \mathrm{dL})$, memberi pengaruh berbeda nyata terhadap kelompok dosis $20 \mathrm{~g} /$ hari/BB $(183,00 \mathrm{mg} / \mathrm{dL})$, namun sangat berbeda nyata terhadap kelompok normal $(89,00 \mathrm{mg} / \mathrm{dL})$. Pada tabel terlihat nilai rata-rata kadar kolesterol terendah adalah pada kelompok normal yaitu $89,00 \mathrm{mg} / \mathrm{dLdan}$ nilai rata-rata kadar kolesterol tertinggi yaitu 179,60 mg/dL pada kelompok dosis $25 \mathrm{~g} /$ hari/BB (Tabel 1). 
Nilai rata-rata kadar kolesterol pada tahap ketiga setelah pemberian sampel tepung tempe sebanyak $10 \mathrm{~g} / \mathrm{hari} / \mathrm{BB}, 20 \mathrm{~g} / \mathrm{hari} / \mathrm{BB}$ dan $25 \mathrm{~g} / \mathrm{hari} / \mathrm{BB}$, menunjukkan kelompok hiperkolesterol $(212,00 \mathrm{mg} / \mathrm{dL})$ sangat berbeda nyata terhadap semua kelompok perlakuan. Pada kelompok normal $(90,80 \mathrm{mg} / \mathrm{dL})$ memberi pengaruh berbeda nyata terhadap dosis 25 $\mathrm{g} /$ hari/BB (107,00 mg/dL) namun sangat berbeda nyata terhadap kelompok hiperkolesterol $(212,00 \mathrm{mg} / \mathrm{dL})$. Pada dosis $10 \mathrm{~g} / \mathrm{hari} / \mathrm{BB}(142,50 \mathrm{mg} / \mathrm{dL})$ memberi pengaruh berbeda tidak nyata terhadap dosis $20 \mathrm{~g} / \mathrm{hari} / \mathrm{BB}(149,75 \mathrm{mg} / \mathrm{dL})$ namun sangat berbeda nyata terhadap kelompok normal $(90,80 \mathrm{mg} / \mathrm{dL})$. Pada dosis $20 \mathrm{~g} / \mathrm{hari} / \mathrm{BB}(149,75 \mathrm{mg} / \mathrm{dL})$ memberi pengaruh berbeda nyata terhadap dosis $25 \mathrm{~g} / \mathrm{hari} / \mathrm{BB}(107,00 \mathrm{mg} / \mathrm{dL})$ namun sangat berbeda nyata terhadap kelompok normal $(90,80 \mathrm{mg} / \mathrm{dL})$. Pada tabel terlihat nilai rata-rata kadar kolesterol terendah adalah pada kelompok normal yaitu 90,80 mg/dL dan nilai rata-rata kadar kolesterol tertinggi yaitu 212,00 mg/dL pada kelompok hiperkolesterol (Tabel 1).

Pengukuran kadar kolesterol darah pada hewan uji mencit (Mus musculus) dilakukan sebanyak tiga tahap. Pada tahap kedua yaitu setelah pemberian pakan kolesterol selama 14 hari dengan menggunakan kuning telur untuk meningkatkan kadar kolesterol hewan uji. Kelompok yang diberi pakan kolesterol kadar kolesterolnya meningkat. Menurut Erni et all (2014) ratarata kadar kolesterol mencit jantan yang masih normal yaitu 40-130 mg/dL. Hal ini menunjukkan bahwa pemberian kuning telur pada pakan hewan uji mencit (Mus musculus) dapat meningkatkan kadar kolesterol bahkan sampai hiperkolesterolemia.

Pakan tinggi kolesterol yang digunakan dalam penelitian ini yakni kuning telur ayam ras. Berdasarkan penelitian Bambang (2003) rata-rata LDL dalam darah tikus yang diberi pakan telur ayam ras yang telah dikukus yakni sebesar 103,13 mg/dL sedangkan rata-rata LDL dalam darah tikus yang diberi pakan telur ayam kampung yang telah dikukus yakni sebesar 13,86 $\mathrm{mg} / \mathrm{dL}$. Hal tersebut menunjukkan bahwa kuning telur ayam ras memiliki pengaruh yang lebih tinggi terhadap peningkatan kadar kolesterol dibandingkan menggunakan kuning telur ayam kampung.

Menurut (Komala, 2008 dalam Muharlien, 2010), mengatakan bahwa kandungan zat gizi telur antara lain air 73,7\%, protein 12,9\%, lemak 11,2\% dan karbohidrat 0,9\%, dan hampir semua lemak dalam telur terdapat dalam kuning telur yaitu mencapai 32\% sedangkan pada putih telur kandungannya sangat sedikit, sementara kuning telur merupakan komponen lemak tertinggi, yang terdiri atas 65,50\% trigliserida, 5,20\% kolesterol, dan 28,30\% fosfolipid. Deposisi kolesterol dalam telur tergantung dari pakan dan lemak yang dikonsumsi.

Pemberian tepung tempe dengan tiga dosis yang berbeda yakni $10 \mathrm{~g} / \mathrm{hari} / \mathrm{BB}, 20$ $\mathrm{g} /$ hari/BB dan $25 \mathrm{~g} / \mathrm{hari} / \mathrm{BB}$ menunjukkan adanya penurunan kadar kolesterol total darah mencit. Pada kelompok mencit yang diberi tepung tempe sebanyak $10 \mathrm{~g} / \mathrm{hari} / \mathrm{BB}$ mengalami penurunan kadar kolesterol sebesar 142,50 mg/dl, pada kelompok mencit yang diberi tepung tempe sebanyak $20 \mathrm{~g} / \mathrm{hari} / \mathrm{BB}$ mengalami penurunan sebesar 149,75 mg/dL, begitupun pada kelompok mencit yang diberi tepung tempe sebanyak $25 \mathrm{~g} / \mathrm{hari} / \mathrm{BB}$ mengalami penurunan sebesar 107,00 mg/dL. Berdasarkan uraian diatas, dapat disimpulkan bahwa baik dosis 10 g/hari/BB, $20 \mathrm{~g} /$ hari/BB dan $25 \mathrm{~g} / \mathrm{hari} / \mathrm{BB}$ memberikan efek penurunan terhadap kolesterol total. Pemberian dosis $25 \mathrm{~g} / \mathrm{hari} / \mathrm{BB}$ menunjukkan dosis terbaik dalam menurunkan kadar kolesterol total dalam penelitian ini. Hal ini disebabkan karena adanya kandungan bahan aktif dalam tepung tempe yaitu isoflavon. Tempe merupakan olahan kedelai dengan fermentasi kapang Rhizopus.Kapang yang sering digunakan dalam pembuatan tempe adalah Rhizopus oligosporus dan Rhizopus orizae. Kandungan senyawa kimia dalam tempe adalah isoflavon. Menurut Handayani (2008) isoflavon adalah salah satu golongan dari kelompok flavonoida. Flavonoida adalah satu golongan senyawa metabolit sekunder yang banyak terdapat pada tumbuh-tumbuhan, khususnya Leguminaceae, sedangkan menurut Ariani (2009), isoflavon adalah salah satu bentuk flavonoid yang banyak ditemukan dalam bahan alam. Senyawa flavonoid yang terisolsai dan teridentifikasi dalam kedelai semuanya dalam bentuk isoflavon. 
Flavonoid merupakan kelompok polifenol dan diklasifikasikan berdasarkan struktur kimia serta biosintesisnya. Struktur dasar flavonoid terdiri dari dua gugus aromatik yang digabungkan oleh jembatan karbon $\left(\mathrm{C}_{6}-\mathrm{C}_{3}-\mathrm{C}_{6}\right)$. Pembagian kelompok flavonoid didasarkan pada perbedaan struktur terutama pada subtitusi karbon pada gugus aromatik sentral dengan beragamnya aktivitas farmakologi yang ditimbulkan (Alfaridz dan Riezki, 2018).

Isoflavon tergolong kelompok flavonoid, senyawa polifenolik yang banyak ditemukan dalam buah-buahan, sayur-sayuran dan biji-bijian. Senyawa isoflavon merupakan salah satu komponen yang juga mengalami metabolisme. Senyawa isoflavon ini pada kedelai berbentuk senyawa konjugat dengan senyawa gula melalui ikatan -0- glikosidik. Selama proses fermentasi ikatan -0- glikosidik terhidrolisis, sehingga dibebaskan senyawa gula dan isoflavon aglikon yang bebas. Senyawa isoflavon aglikon ini dapat mengalami transformasi lebih lanjut membentuk transformasi baru. Hasil transformasi lebih lanjut dari senyawa aglikon ini justru menghasilkan senyawa-senyawa yang mempunyai aktivitas biologi yang tinggi (Amaliah, 2010).

Aktivitas fisiologis dari isoflavon yang menonjol adalah aktivitas antioksidan. Antioksidan merupakan senyawa pemberi elektron (electron donor) atau reduktan. Senyawa antioksidan memiliki berat molekul kecil, tetapi mampu menginaktivasi berkembangnya reaksi oksidasi dengan cara mencegah terbentuknya radikal. Antioksidan juga merupakan senyawa yang dapat menghambat reaksi oksidasi, dengan mengikat radikal bebas dan molekul yang sangat reaktif (Winarsari, 2007 dalam Latifah, 2015).

\section{Kesimpulan}

Berdasarkan hasil penelitian pemberian tepung tempe berpengaruh terhadap penurunan kadar kolesterol total darah mencit(Mus musculus) yang mengalami hiperkolesterol baik pada dosis $10 \mathrm{~g} / \mathrm{hari} / \mathrm{BB}, 20 \mathrm{~g} / \mathrm{hari} / \mathrm{BB}$ dan $25 \mathrm{~g} / \mathrm{hari} / \mathrm{BB}$. Pemberian dosis $25 \mathrm{~g} / \mathrm{hari} / \mathrm{BB}$ menunjukkan dosis terbaik dalam menurunkan kadar kolesterol total dalam penelitian ini yakni $179,60 \mathrm{mg} / \mathrm{dL}$ menurun menjadi $107,00 \mathrm{mg} / \mathrm{dL}$.

\section{Referensi}

Alfaridz, Faizal \& Riezki., A. (2018). Review Jurnal Klasifikasi dan Aktivitas Farmakologi Senyawa Aktif Flavonoid. Jurnal Farmaka Suplemen 16 (3).

Amaliah, Firda., N. (2010). Uji Kandungan Senyawa Isoflavon Kalus Kedela (Glicine max (L) Merr Pada Media P5 dengan Penambahan PEG (Polyethylene Glicol) 6000. Skripsi. Universitas Islam Negeri Maulana Malik Ibrahim Malang.

Ariani, Sri., R D \& Wiji., H. (2009). Analisis Isoflavon dan Uji Antioksidan pada Tempe dengan Variasi Lama Waktu Fermentasi dan Metode Ekstraksi. Prosiding Seminar Nasional Kimia dan Pendidikan Kimia FKIP UNS Surakarta.

Astawan, Made., Tutik., W, \& Lulu., M. (2017). Tempe Sumber Zat Gizi dan Komponen Bioaktif untuk Kesehatan. Bogor. PT Penerbit IPB Press.

Bambang, Dwiloka. (2003). Efek Kolesterolemik Berbagai Telur. Teknologi Produksi Ternak, Fakultas Peternakan, Universitas Diponegoro. Semarang.

Erni., A. Mu'nisa \& A. Faridah., A. (2014). Pengaruh Pemberian Minyak Mandar yang ditambahkan Bubuk Daun Sukun (Arthocarpus altilis) terhadap Kadar Kolesterol Mencit (Mus musculus). Jurnal Bionature 15 (2). 
Fauziana, Ardia. (2016). Pengaruh Perasan Buah Okra (Albemoschus esculantus L.) terhadap Kadar Kolesterol Mencit (Mus musculus L.) BALB-C dan Pemanfaatannya sebagai LEAFLET. Skripsi. Fakultas Keguruan dan Ilmu Pendidikan Universitas Jember.

Handayani, Sri. (2008). Kandungan Senyawa Isoflavon dalam Tempe dan Manfaatnya bagi Kesehatan. Tim PPM Pendidikan Kimia FMIPA UNY.

Latifah. (2015). Identifikasi Golongan Senyawa Flavonoid dan Uji Aktivitas Antioksidan pada Ekstrak Rimpang Kencur (Kaempferia galangan L) dengan Metode DPPH (1,1 Difenil-2Pikrilhidrazil). Skripsi. Universitas Islam Negeri Malik Ibrahim Malang.

Mu'nisa A., Wasmen M., Wresdiyati T., \& Nastiti K. (2008). Perbaikan aktivitas Antioksidan pada Jaringan Kelinci hiperkolesterolemia dengan Pemberian Ekstrak Daun Cengkeh. Jurnal Veteriner, 13, (3), 272-277.

Muharlien. (2010). Meningkatkan Kualitas Telur Melalui Penambahan Teh Hijau dalam Pakan Ayam Petelur. Jurnal Ilmu dan Teknologi Hasil Ternak 5 (1).

Priastiti, Della A., \& Niken., P. (2013). Perbedaan Kadar Kolesterol LDL Penderita Dislipidemia pada Pemberian Tempe Kedelai Hitam dan Tempe Kedelai Kuning. Journal of Nutrition College, 2 (2).

Purwoko, Tjahjadi. (2004). Kandungan Isoflavon Aglikonpada Tempe Hasil Fermentasi Rhizopus microsporus var. oligosporus: Pengaruh Perendaman. Jurnal BioSMART 6 (2).

Rahayu, T. (2005). Kadar Kolesterol Darah Tikus Putih (Rattus norvegicus L) setelah Pemberian Cairan Kombucha per-oral. Jurnal Penelitian Sains \& Teknologi, 6 (2).

Riset Kesehatan Dasar. (2013). Riskesdas. Badan Penelitian dan Pengembangan kesehatan Kementrian kesehatan RI.

Suwarno, Maryani., made., A., Tutik., Wi, Sri W, Siti H B \& Mursyid. (2014). Evaluasi keamanan Tempe dari kedelai Transgenik melalui Uji Subkronis pada Tikus. Jurnal Veteriner 15 (3).

\begin{tabular}{|l|l|}
\hline Heryl Rumtal & $\begin{array}{l}\text { S.Si. Jurusan Biologi, Fakultas Matematika dan Ilmu } \\
\text { Pengetahuan Alam, Universitas Negeri Makassar } \\
\text { Email: heryljr17@gmail.com }\end{array}$ \\
\hline Rosdiana Ngitung & $\begin{array}{l}\text { Dr, Ir, M.P, Dosen Jurusan Biologi, Fakultas Matematika dan } \\
\text { Ilmu Pengetahuan Alam, Universitas Negeri Makassar } \\
\text { Email: } \underline{\text { rosdiana.ngitung@gmail.com }}\end{array}$ \\
\hline A. Mu'nisa & $\begin{array}{l}\text { Dr, S, Si, M.Si, Dosen Jurusan Biologi, Fakultas Matematika dan } \\
\text { Ilmu Pengetahuan Alam, Universitas Negeri Makassar } \\
\text { Email: andi.munisa@unm.ac.id }\end{array}$ \\
\hline
\end{tabular}

